PALEOCEANOGRAPHY, VOL. 8, NO. 6, PAGES 859-873, DECEMBER 1993

\section{STRONTIUM ISOTOPE STRATIGRAPHY IN THE LATE CRETACEOUS: NUMERICAL CALIBRATION OF THE ST ISOTOPE CURVE AND INTERCONTINENTAL CORRELATION FOR THE CAMPANIAN}

J. M. McArthur, ${ }^{1}$ M. F. Thirlwall, ${ }^{2}$ M. Chen, ${ }^{1}$ A. S. Gale, ${ }^{3}$ and W. J. Kennedy' of the belemnite Gonioteuthis granulataquadrata, has an ${ }^{87} \mathrm{Sr} /{ }^{86} \mathrm{Sr}$ of $0.707473 \pm 5$. This is within error of the values of $0.707457 \pm 16$ for this boundary in the U.S. western interior (base of the Scaphites leei III zone) and $0.707479 \pm 9$ for this boundary in the English Chalk (top of the Marsupites testudinarius zone). In Kronsmoor, the boundary between the Campanian and Maastrichtian stages, taken here as the level of first occurrence of the belemnite Belemnella lanceolata, has an ${ }^{87} \mathrm{Sr} /{ }^{86} \mathrm{Sr}$ of $0.707723 \pm 4$. This is within error of the values of $0.707725 \pm 20$ for this boundary in the U.S. western interior (base of the Baculites eliasi zone) and $0.707728 \pm 5$ for this boundary in the English Chalk (defined as in Germany).

\section{INTRODUCTION}

Dating and correlation with $\mathrm{Sr}$ isotopes are now commonplace (for reviews and applications see Elderfield [1986], Miller et al. [1988, 1991], Veizer [1989], McArthur et al. $[1990,1992,1993 a, b]$ and references therein). For the method to be useful, ${ }^{87} \mathrm{Sr} /{ }^{86} \mathrm{Sr}$ in samples of unknown age must be matched to standard curves that are calibrated against well-documented biostratigraphy, magnetostratigraphy, and numeric age. As currently practiced, much strontium isotope stratigraphy assumes a high quality for this stratigraphic framework, but this quality, and the quality of accompanying assignments of numeric age, are generally overestimated. Some pointers to the real errors inherent in the stratigraphy, and numeric age assignment, used for $\mathrm{Sr}$ isotope work have recently been given by Miller et al. [1988, 1991].

Most extant Sr isotope curves are based on Deep Sea Drilling Project/Ocean Drilling Project (DSDP/ODP) sections that are calibrated against magnetostratigraphy and nannofossil and microfossil biostratigraphy, whereas the correlation and dating of most continental sequences is based on zonation with macrofossils. Integration of these different schemes is not straightforward and can be assisted by the use of $\mathrm{Sr}$ isotopes. 
This paper represents a step toward such integration by providing a detailed curve of ${ }^{87} \mathrm{Sr} /{ }^{86} \mathrm{Sr}$ through a standard section of the Upper Cretaceous European Chalk at Lägerdorf and Kronsmoor in northwestern Germany. We use this curve to correlate to the U.S. western interior, and to the United Kingdom.

\section{SAMPLES ANALYZED}

To define our ${ }^{87} \mathrm{Sr} /{ }^{86} \mathrm{Sr}$ curve, we have analyzed belemnites and bulk samples of nannofossil chalk from quarries near Lägerdorf and Kronsmoor, $40 \mathrm{~km}$ northwest of Hamburg, Germany [Schỏnfeld et al., 1993]. For the purposes of correlating other sections to Germany, we have analyzed nannofossil chalk and macrofossils (fragments of inoceramid bivalves, brachiopods, belemnites, and an oyster) from a borehole cored through the English Chalk at Trunch, Norfolk, United Kingdom [McArthur et al., 1993a], and fragments of aragonitic ammonites and calcitic inoceramid bivalves from the United States western interior [McArthur et al., 1993b].

\section{STRATIGRAPHY}

It is important to note that the boundaries between Upper Cretaceous stages and substages have not yet been defined by the International Commission on Stratigraphy and that boundaries vary widely in their position from author to author, as do boundaries defined by different fossil groups. For a general discussion of Upper Cretaceous stage boundaries, see the works by Birkelund et al. [1984] and Hancock [1991, 1993].

The section at Lägerdorf/Kronsmoor is one of the best available for the northwestern European Upper Cretaceous Chalk. Its stratigraphy is summarized by Schönfeld et al. [1993]; relevant details are briefly repeated here. Four meters of unexposed section separate the lowermost strata in Kronsmoor from the uppermost strata in Lagerdorf. The stratigraphy of the combined section is given in Figure 1. The difference in sedimentological detail shown in the upper (Kronsmoor) and lower (Lägerdorf) parts of Figure 1 are due to their derivation from different authors (see section 3.1 and 3.2). Nineteen macrofossil zones can be recognized, based on the distribution of ammonites, belemnites, inoceramid bivalves, echinoids and crinoids, together with 15 benthic foraminiferal zones (see sections 3.1 and 3.2). Stratigraphic levels are given in meters from a prominent Lower Campanian marl seam (M1) in Lägerdorf that is widely traceable in northwestern Europe. Bedding is picked out by layers of flint nodules, marl seams, marly chalk beds, and beds containing pyritized burrows. The chalk is friable and white and consists of $>85 \%$ nannofossils, together with minor amounts of calcispheres, foraminifera, macrofossil debris (fragments of bryozoa, echinoids, bivalves, and brachiopods), and generally less than $10 \%$ clastic material [Schulz et al., 1984; Schönfeld et al., 1991]. Certain levels, such as the Santonian/Campanian boundary, locally contain up to $40 \%$ inoceramid prisms. Following two of the recommendations of Birkelund et al. [1984], the base of the Campanian in Lägerdorf has been drawn at the level of first occurrence of the belemnite Gonioteuthis granulataquadrata, and the base of the Maastrichtian in Kronsmoor has been drawn at the level of first occurrence of the belemnite Belemnella lanceolata.

\subsection{Lägerdorf}

The lithostratigraphy and macrofossil biostratigraphy are based on the works by Emst [1963], Schultz [1978], and Schultz et al. [1984], which are summarised by Schônfeld et al. [1993]. Thirteen macrofossil zones can be correlated widely in the Chalk of northwestern Europe. Eleven benthic foraminiferal zones of more local applicability were established by Koch [1977] and Schōnfeld [1988]. The nannofossil zonation is from Burnett [1990] and Schönfeld and Burnett [1991] and is based on the standard calcareous nannofossil zonation scheme (CC zones of Sissingh [1977] in Figure 1), as amended by Perch-Nielsen [1979, 1985]. The nannofossil zonation has been refined by the definition of boreal subzones (CC/B zones of Burnett [1990] in Figure 1).

\subsection{Kronsmoor}

The lithostratigraphy is from Schulz [1978], the macrofossil zonation is from Schulz [1979], the benthic microfossil zonation follows Schönfeld [1988], the microbrachiopod zonation is after Surlyk [1982], and the nannofossil zonation is from Burnett [1990]. Some levels in the Kronsmoor section has been biostratigraphically correlated to DSDP sites 548A, 549 , and 551 using calcareous benthic foraminifera and nannoplankton [Schönfeld and Burnett, 1991].

\section{METHODS AND RESULTS}

The analytical methodology is that given by McArthur et al [1992, 1993a]. Isotopic measurements were made using a model VG 354 multicollector mass spectrometer utilizing multidynamic routines [Thirlwall, 1991]. All ${ }^{87} \mathrm{Sr} /{ }^{86} \mathrm{Sr}$ data have been normalized to a value of 0.1194 for ${ }^{86} \mathrm{Sr} /{ }^{88} \mathrm{Sr}$ and adjusted to an ${ }^{87} \mathrm{Sr} /{ }^{86} \mathrm{Sr}$ value of 0.710248 for standard reference material SRM 987. The adjustment was based on the mean ${ }^{87} \mathrm{Sr} /{ }^{86} \mathrm{Sr}$ for SRM 987 for periods of measurement between major machine maintenance. Adjustment never exceeded $18 \times 10^{-6}$ and was generally less than half this value. Two standards (SRM 987) were run per turret of 14 samples; based on these accumulated replicates, the reproducibility of our measurements of ${ }^{87} \mathrm{Sr} /{ }^{\beta 6} \mathrm{Sr}$ is $\pm 18 \times 10^{-6}$ for single determinations, $\pm 13 \times 10^{-6}$ for duplicates, and $\pm 10 \times 10^{-6}$ for triplicates, where the error is at 2 standard errors ( 2 s.e), calculated as $2 \times$ standard deviation $/(n)^{1 / 2}$, where $n$ is the number of determinations. The mean ${ }^{87} \mathrm{Sr} /{ }^{86} \mathrm{Sr}$ for 11 subsamples of aragonite from a modern nautiloid and 5 samples of seawater from the North Atlantic is $0.709175 \pm 4$ (2 s.e.), after adjustment to SRM 987 of 0.710248.

The data are given in Table 1 and are plotted against stratigraphic level in Figures 2-5 and against numeric age in Figure 6. In all figures, error bars are drawn at 2 s.e. Linear regressions are done according to the method of York [1967], using errors of $\pm 18 \times 10^{-6}$ in ${ }^{87} \mathrm{Sr} /{ }^{86} \mathrm{Sr}$ and $0.1 \mathrm{~m}$ in stratigraphic level. With a Campanian sedimentation rate (present compaction) of 11 meters/m.y. (271 m in $12.2 \mathrm{~m} . \mathrm{y}$.) (Figures 2 and 5), a stratigraphic accuracy of $\pm 0.1 \mathrm{~m}$ is equivalent to $\pm 0.005 \mathrm{~m}$.y., which is the precision of relative ages within our section. Although precise relative to each other, these numeric ages may be systematically inaccurate by up to $\pm 0.5 \mathrm{~m} . \mathrm{y}$., as these are the uncertainties of the ages of stage boundaries [Obradovich, 1993] (see section 5.5). 

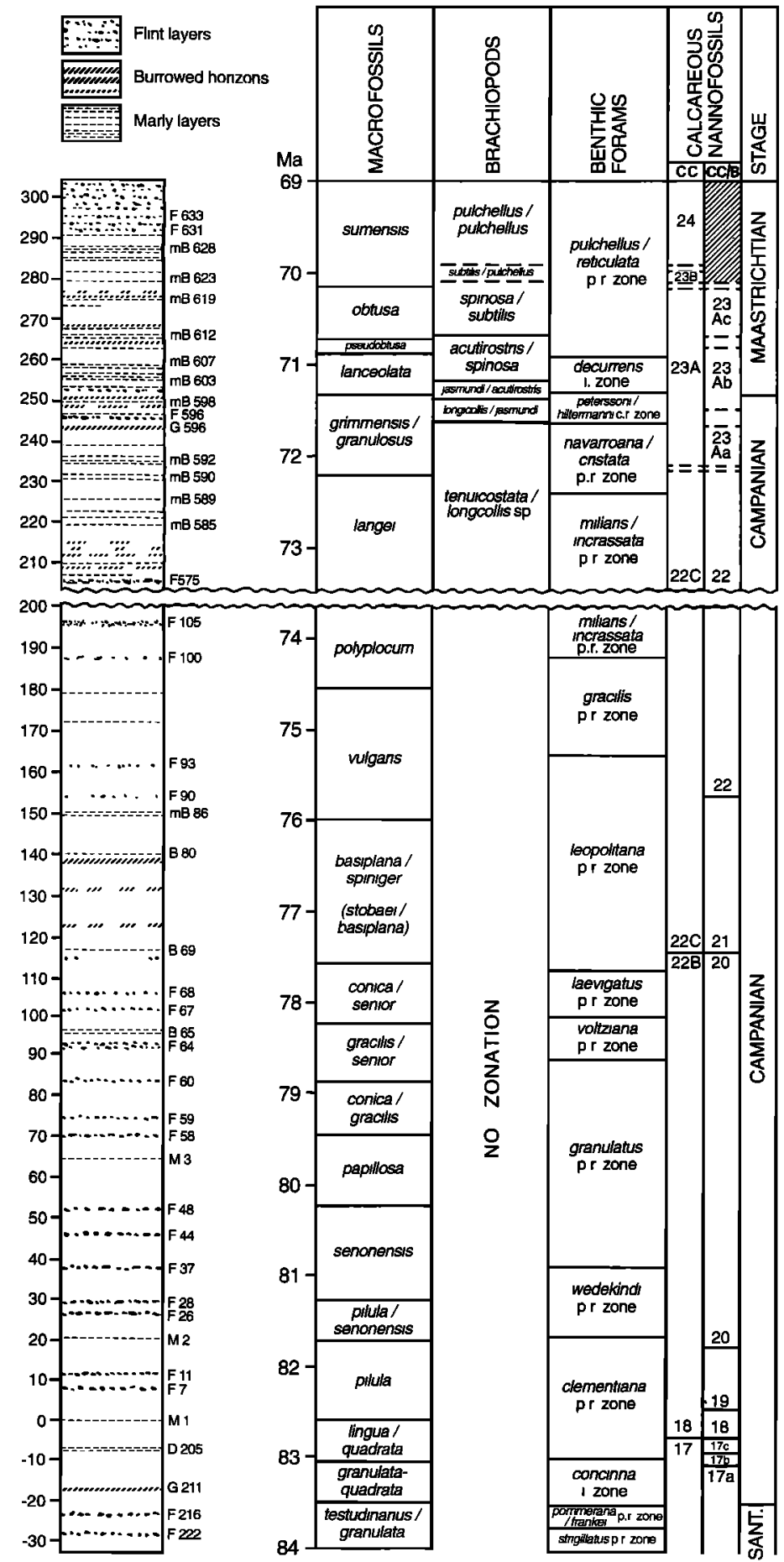

Fig. 1. Stratigraphy of the Chalk at Lägerdorf/Kronsmoor. The base of the exposed section is at $-62 \mathrm{~m}$ and the top is at $300 \mathrm{~m}$. Nannofossils zones; CC are zones of Sissingh [1977], CC/B are zones of Sissingh [1977] as modified by Burnett [1990]. The base of the Maastrichtian is at $251 \mathrm{~m}$ and the base of the Campanian is at $-20 \mathrm{~m}$. Note that in McArthur et al. [1992], the miliaris/incrassata zone was incorrectly labelled the miliaris/cristata zone. The difference in sedimentological detail between the upper and lower parts of the section results from their derivation from different sources (see text for details). 


\section{DISCUSSION}

\subsection{Diagenesis}

The chalk at Lägerdorf/Kronsmoor is friable and disaggregates in water; on this criteria it is essentially uncemented, a fact which suggests it has undergone little diagenetic alteration. Because of this, we believe it is recording an accurate record of marine ${ }^{87} \mathrm{Sr} /{ }^{86} \mathrm{Sr}$, despite the presence of a little microspar in lower stratigraphic levels of Lägerdorf [Schönfeld et al., 1991]. Paired samples of calcite from whole belemnites and nannofossil chalk from eight levels in the sections have been analyzed for ${ }^{87} \mathrm{Sr} /{ }^{86} \mathrm{Sr}$, and for each pair the ${ }^{87} \mathrm{Sr} /{ }^{86} \mathrm{Sr}$ values are within error of each other (Table 1). This further suggests that our nannofossil samples are well preserved; it seems unlikely that diagenesis could affect equally massive low-magnesium calcite in belemnite guards and micron-sized nannoplankton remains, in view of their greatly different mass/surface area ratios. Samples from the United States were pristine, as judged by $X$ ray diffraction, scanning electron microscopy, chemical analysis, and optical microscopy; details are given in McArthur et al. [1993b]. These samples preserve their original ${ }^{87} \mathrm{Sr} /{ }^{86} \mathrm{Sr}$ values. In the English Chalk of Norfolk, which is more cementedthan the German Chalk, diagenetic alteration has increased ${ }^{87} \mathrm{Sr} /{ }^{86} \mathrm{Sr}$ in nannofossil matrix by $30 \times 10^{-6}$ compared to ${ }^{87} \mathrm{Sr} /{ }^{86} \mathrm{Sr}$ in macrofossils from the same stratigraphic level [McArthur et al., 1993a, McArthur, 1993]. We therefore correct for this diagenetic effect by subtracting $30 \times 10^{-6}$ from the ${ }^{87} \mathrm{Sr} /{ }^{86} \mathrm{Sr}$ values of the Norfolk nannofossil samples.

\subsection{Sr Isotope Curve for Germany}

The ${ }^{87} \mathrm{Sr} /{ }^{86} \mathrm{Sr}$ data increases from $\leq 0.70747$ to $\geq 0.70777$ with increasing stratigraphic height through the section. The quality of our isotopic measurements appears good when judged by the degree of concordance of adjacent data (Figure 2). The data appear to define three linear segments, which are separated by inflections in the Upper Campanian G. vulgaris zone at $162 \mathrm{~m}$ and at $-6 \mathrm{~m}$ in the lowermost Campanian I. lingua/G. quadrata zone. In section 5.5 we discuss York [1967] regressions between ${ }^{87} \mathrm{Sr} /{ }^{86} \mathrm{Sr}$, stratigraphic level, and numeric age. Data may plateau over short intervals between $-2 \mathrm{~m}$ and $10 \mathrm{~m}$ (upper part of the 1. lingua/G. quadrata zone and lower half of the Offaster pilula zone), between $52 \mathrm{~m}$ and $65 \mathrm{~m}$ (Galeola papillosa zone), and between $150 \mathrm{~m}$ and $162 \mathrm{~m}$ (bottom half of the G. vulgaris zone), although none of these plateau are unequivocally defined.

Two possible short-term excursions in ${ }^{87} \mathrm{Sr} /{ }^{86} \mathrm{Sr}$ are present; sample $51(139.7 \mathrm{~m})$ and $46(103.7 \mathrm{~m})$ have ${ }^{87} \mathrm{Sr} /{ }^{86} \mathrm{Sr}$ that is reproducibly lower by about $20-30 \times 10^{-6}$ than expected for their stratigraphic level. A belemnite from $137.7 \mathrm{~m}$ has an ${ }^{87} \mathrm{Sr} /{ }^{86} \mathrm{Sr}$ similar to that of sample 51 , but an intervening nannofossil sample (B80 -1.1, $138.7 \mathrm{~m}$ ) is not anomalous (Table 1). The reproducibility of the ${ }^{87} \mathrm{Sr} /{ }^{86} \mathrm{Sr}$ data for these samples suggests that these anomalies are real. They may result from localized diagenesis, or they may be recording real excursions in marine ${ }^{87} \mathrm{Sr} /{ }^{86} \mathrm{Sr}$. The nannofossil assemblages in samples 46 and 51 are consistent with their stratigraphic level (J. A. Burnett, personal communication, 1992), so the anomalous ${ }^{87} \mathrm{Sr} /{ }^{86} \mathrm{Sr}$ cannot be explained by errors in curation.
TABLE 1. Isotopic Data for Nannofossil Chalks and Belemnites From Lagerdorf / Kronsmoor, Germany

\begin{tabular}{|c|c|c|c|c|c|}
\hline $\begin{array}{l}\text { Sample } \\
\text { Number } \\
\end{array}$ & $\begin{array}{c}\text { Age, } \\
\text { Ma } \\
\end{array}$ & Level* & $\begin{array}{c}\text { Sample } \\
87 \mathrm{Sr} / 86 \mathrm{Sr} \\
\end{array}$ & Error & $\begin{array}{c}\text { Mean } \\
87 \mathrm{Sr} / 86 \mathrm{Sr} \\
\end{array}$ \\
\hline \multicolumn{6}{|c|}{ Kronsmoor Quarry } \\
\hline \multirow[t]{2}{*}{35} & 69.43 & 292.5 & 0.707768 & 9 & 0.707766 \\
\hline & & & 0.707764 & 8 & \\
\hline 34 & 69.57 & 289.5 & 0.707770 & 8 & 0.707770 \\
\hline 32 & 69.76 & 285.1 & 0.707773 & 11 & 0.707773 \\
\hline K-Bel-3 & 69.88 & 282.5 & 0.707769 & 11 & 0.707769 \\
\hline 31 & 69.90 & 282.1 & 0.707764 & 17 & 0.707764 \\
\hline \multirow[t]{3}{*}{30} & 69.98 & 280.4 & 0.707748 & 7 & 0.707757 \\
\hline & & & 0.707757 & 10 & \\
\hline & & & 0.707766 & 7 & \\
\hline 29 & 70.17 & 276.2 & 0.707750 & 9 & 0.707750 \\
\hline 26 & 70.52 & 268.4 & 0.707754 & 10 & 0.707754 \\
\hline 25 & 70.68 & 264.8 & 0.707741 & 9 & 0.707741 \\
\hline 23 & 70.82 & 261.6 & 0.707726 & 8 & 0.707726 \\
\hline 22 & 71.00 & 257.6 & 0.707733 & 9 & 0.707733 \\
\hline K-Bel-2 & 71.01 & 257.5 & 0.707738 & 9 & 0.707738 \\
\hline 16 & 71.10 & 255.4 & 0.707742 & 9 & 0.707742 \\
\hline 15 & 71.19 & 253.5 & 0.707719 & 10 & 0.707719 \\
\hline \multirow[t]{2}{*}{14} & 71.26 & 251.9 & 0.707721 & 8 & 0.707725 \\
\hline & & & 0.707730 & 6 & \\
\hline 21 & 71.32 & 250.6 & 0.707723 & 7 & 0.707723 \\
\hline \multicolumn{6}{|c|}{ Campanian - Maastrichtian Boundary at $251 \mathrm{~m}$} \\
\hline 18 & 71.42 & 248.4 & 0.707710 & 10 & 0.707710 \\
\hline 19 & 71.48 & 246.9 & 0.707725 & 11 & 0.707725 \\
\hline 39 & 71.77 & 240.5 & 0.707700 & 8 & 0.707700 \\
\hline K-Bel-1 & 71.82 & 239.5 & 0.707711 & 10 & 0.707711 \\
\hline 37 & 71.98 & 235.9 & 0.707696 & 8 & 0.707696 \\
\hline 13 & 72.20 & 231.1 & 0.707693 & 7 & 0.707693 \\
\hline \multirow[t]{2}{*}{11} & 72.28 & 229.3 & 0.707697 & 8 & 0.707696 \\
\hline & & & 0.707695 & 9 & \\
\hline 12 & 72.37 & 227.3 & 0.707686 & 7 & 0.707686 \\
\hline 9 & 72.51 & 224.1 & 0.707684 & 7 & 0.707684 \\
\hline 7 & 72.57 & 222.7 & 0.707689 & 9 & 0.707689 \\
\hline 8 & 72.66 & 220.8 & 0.707675 & 9 & 0.707675 \\
\hline 3 & 72.71 & 219.7 & 0.707688 & 9 & 0.707688 \\
\hline 5 & 72.88 & 215.9 & 0.707680 & 8 & 0.707680 \\
\hline 6 & 73.12 & 210.5 & 0.707667 & 10 & 0.707667 \\
\hline 2 & 73.35 & 205.4 & 0.707664 & 9 & 0.707664 \\
\hline \multirow[t]{3}{*}{1} & 73.46 & 203.0 & 0.707667 & 10 & 0.707663 \\
\hline & & & 0.707659 & 9 & \\
\hline & \multicolumn{4}{|c|}{ Lagerdorf Quarry } & \\
\hline 63 & 73.93 & 192.5 & 0.707651 & 9 & 0.707651 \\
\hline 52 & 74.18 & 187.0 & 0.707645 & 7 & 0.707645 \\
\hline L-Bel-5 & 74.18 & 187.0 & 0.707635 & 10 & 0.707635 \\
\hline \multirow[t]{2}{*}{54} & 74.38 & 182.5 & 0.707633 & 11 & 0.707633 \\
\hline & & & 0.707633 & 8 & \\
\hline 55 & 74.61 & 177.5 & 0.707628 & 9 & 0.707628 \\
\hline \multirow[t]{2}{*}{56} & 74.84 & 172.3 & 0.707630 & 9 & 0.707616 \\
\hline & & & 0.707602 & 9 & \\
\hline \multirow[t]{3}{*}{57} & 75.08 & 167.0 & 0.707620 & 9 & 0.707620 \\
\hline & & & 0.707618 & 10 & \\
\hline & & & 0.707621 & 6 & \\
\hline
\end{tabular}


TABLE 1. (continued)

\begin{tabular}{|c|c|c|c|c|c|c|c|c|c|c|c|}
\hline \multicolumn{6}{|c|}{ TABLE 1 . (continued) } & \multicolumn{6}{|c|}{ TABLE 1. (continued) } \\
\hline $\begin{array}{l}\text { Sample } \\
\text { Number }\end{array}$ & $\begin{array}{c}\text { Age, } \\
\text { Ma }\end{array}$ & Level* & $\begin{array}{c}\text { Sample } \\
87 \mathrm{Sr} / 86 \mathrm{Sr} \\
\end{array}$ & Error & $\begin{array}{c}\text { Mean } \\
87 \mathrm{Sr} / 86 \mathrm{Sr} \\
\end{array}$ & Sarrple & $\begin{array}{c}\text { Age, } \\
\mathrm{Ma}\end{array}$ & Level* & $\begin{array}{c}\text { Sample } \\
87 \mathrm{Sr} / 86 \mathrm{Sr}\end{array}$ & Error & $\begin{array}{c}\text { Mean } \\
87 \mathrm{Sr} / 86 \mathrm{Sr} \\
\end{array}$ \\
\hline \multirow[t]{2}{*}{58} & 75.31 & 162.0 & 0.707606 & 6 & 0.707603 & 29 & 79.86 & 60.8 & 0.707525 & 7 & 0.707531 \\
\hline & & & 0.707599 & 10 & & & & & 0.707536 & 10 & \\
\hline \multirow[t]{3}{*}{59} & 75.55 & 156.5 & 0.707605 & 8 & 0.707610 & 27 & 80.07 & 56.2 & 0.707529 & 8 & 0.707529 \\
\hline & & & 0.707613 & 10 & & & & & 0.707529 & 10 & \\
\hline & & & 0.707613 & 9 & & 25 & 80.29 & 51.4 & 0.707538 & 9 & 0.707538 \\
\hline \multirow[t]{2}{*}{60} & 75.69 & 153.5 & 0.707606 & 7 & 0.707611 & 24 & 80.55 & 45.6 & 0.707533 & 7 & 0.707533 \\
\hline & & & 0.707616 & 9 & & 23 & 80.86 & 38.6 & 0.707517 & 10 & 0.707517 \\
\hline \multirow[t]{3}{*}{64} & 75.78 & 151.5 & 0.707604 & 9 & 0.707611 & 22 & 80.92 & 37.2 & 0.707530 & 10 & 0.707530 \\
\hline & & & 0.707619 & 7 & & 18 & 81.15 & 32.2 & 0.707517 & 7 & 0.707517 \\
\hline & & & 0.707609 & 9 & & 17 & 81.19 & 31.4 & 0.707503 & 9 & 0.707511 \\
\hline \multirow[t]{3}{*}{65} & 75.96 & 147.5 & 0.707623 & 9 & 0.707615 & & & & 0.707519 & 9 & \\
\hline & & & 0.707618 & 7 & & 16 & 81.28 & 29.3 & 0.707506 & 12 & 0.707511 \\
\hline & & & 0.707605 & 11 & & & & & 0.707516 & 9 & \\
\hline B80(6.1) & 76.03 & 145.9 & 0.707601 & 9 & 0.707601 & 1 & 81.38 & 27.2 & 0.707527 & 11 & 0.707522 \\
\hline \multirow[t]{2}{*}{$\mathrm{B} 80(2.1)$} & 76.21 & 141.9 & 0.707596 & 9 & 0.707603 & & & & 0.707517 & 10 & \\
\hline & & & 0.707610 & 18 & & 14 & 81.48 & 24.8 & 0.707511 & 10 & 0.707511 \\
\hline $\mathrm{B} 80(1.1)$ & 76.26 & 140.9 & 0.707598 & 10 & 0.707598 & 13 & 81.53 & 23.7 & 0.707519 & 10 & 0.707517 \\
\hline $\mathrm{B} 80(0.2)$ & 76.30 & 140.0 & 0.707617 & 9 & 0.707617 & & & & 0.707515 & 12 & \\
\hline \multirow[t]{2}{*}{51} & 76.31 & 139.7 & 0.707582 & 9 & 0.707577 & 12 & 81.58 & 22.7 & 0.707512 & 9 & 0.707509 \\
\hline & & & 0.707572 & 8 & & & & & 0.707506 & 7 & \\
\hline B80(-1.1) & 76.36 & 138.7 & 0.707600 & 10 & 0.707600 & 9 & 81.64 & 21.4 & 0.707521 & 11 & 0.707521 \\
\hline L-Bel-4 & 76.40 & 137.7 & 0.707573 & 10 & 0.707573 & 6 & 81.70 & 20.0 & 0.707514 & 10 & 0.707514 \\
\hline \multirow[t]{2}{*}{ B69(19.5) } & 76.45 & 136.5 & 0.707613 & 12 & 0.707602 & 5 & 81.78 & 18.2 & 0.707498 & 9 & 0.707498 \\
\hline & & & 0.707591 & 9 & & L-Bel-2 & 81.78 & 18.2 & 0.707495 & 10 & 0.707495 \\
\hline B69(16.8) & 76.58 & 133.8 & 0.707604 & 9 & 0.707604 & 4 & 81.83 & 17.2 & 0.707524 & 9 & 0.707509 \\
\hline B69(12.8) & 76.76 & 129.8 & 0.707604 & 12 & 0.707604 & & & & 0.707493 & 10 & \\
\hline B69(10.1) & 76.88 & 127.1 & 0.707596 & 10 & 0.707596 & 88 & 81.92 & 15.1 & 0.707507 & 10 & 0.707507 \\
\hline$B 69(6.4)$ & 77.04 & 123.4 & 0.707595 & 11 & 0.707595 & 87 & 82.05 & 12.2 & 0.707508 & 9 & 0.707508 \\
\hline \multirow[t]{3}{*}{50} & 77.20 & 120.0 & 0.707580 & 8 & 0.707586 & 86 & 82.10 & 11.1 & 0.707499 & 11 & 0.707499 \\
\hline & & & 0.707591 & 13 & & 85 & 82.20 & 8.8 & 0.707491 & 7 & 0.707497 \\
\hline & & & 0.707586 & 9 & & & & & 0.707503 & 11 & \\
\hline 48 & 77.39 & 115.8 & 0.707589 & 7 & 0.707589 & 84 & 82.32 & 6.3 & 0.707500 & 9 & 0.707500 \\
\hline 47 & 77.84 & 105.7 & 0.707579 & 10 & 0.707579 & 82 & 82.45 & 3.4 & 0.707495 & 7 & 0.707495 \\
\hline $\mathrm{F} 67(2.1)$ & 77.91 & 104.2 & 0.707561 & 10 & 0.707561 & 67 & 82.61 & -0.3 & 0.707497 & 9 & 0.707497 \\
\hline \multirow[t]{3}{*}{46} & 77.93 & 103.7 & 0.707546 & 9 & 0.707546 & 68 & 82.67 & -1.5 & 0.707497 & 9 & 0.707497 \\
\hline & & & 0.707546 & 6 & & 69 & 82.74 & -3.1 & 0.707488 & 7 & 0.707488 \\
\hline & & & 0.707548 & 9 & & 70 & 82.88 & -6.2 & 0.707497 & 9 & 0.707497 \\
\hline F67(1.1) & 77.95 & 103.2 & 0.707572 & 13 & 0.707572 & 71 & 82.93 & -7.3 & 0.707494 & 10 & 0.707494 \\
\hline F67(0.1) & 78.00 & 102.2 & 0.707559 & 9 & 0.707559 & 72 & 83.00 & -8.9 & 0.707509 & 7 & 0.707496 \\
\hline 45 & 78.05 & 101.0 & 0.707559 & 9 & 0.707559 & & & & 0.707482 & 11 & \\
\hline 44 & 78.19 & 98.0 & 0.707570 & 8 & 0.707570 & 73 & 83.18 & -13.0 & 0.707490 & 8 & 0.707490 \\
\hline 43 & 78.29 & 95.8 & 0.707570 & 9 & 0.707570 & 77 & 83.33 & -16.3 & 0.707471 & 11 & 0.707471 \\
\hline 41 & 78.40 & 93.2 & 0.707569 & 6 & 0.707569 & 76 & 83.41 & -17.9 & 0.707475 & 11 & 0.707475 \\
\hline 38 & 78.72 & 86.2 & 0.707551 & 11 & 0.707551 & 75 & 83.45 & -18.9 & 0.707481 & 9 & 0.707481 \\
\hline 37 & 78.90 & 82.2 & 0.707554 & 16 & 0.707554 & \multicolumn{6}{|c|}{ Santonian-Campanian Boundary at $-20 \mathrm{~m}$} \\
\hline 36 & 78.99 & 80.2 & 0.707546 & 11 & 0.707546 & 74 & 83.54 & -20.9 & 0.707463 & 9 & 0.707463 \\
\hline 35 & 79.08 & 78.2 & 0.707541 & 10 & 0.707541 & & & & 0.707462 & 9 & \\
\hline F59(0.1) & 79.28 & 73.7 & 0.707533 & 10 & 0.707533 & 78 & 83.65 & -23.4 & 0.707470 & 7 & 0.707470 \\
\hline 34 & 79.37 & 71.7 & 0.707539 & 10 & 0.707539 & 79 & 83.77 & -26.1 & 0.707468 & 9 & 0.707468 \\
\hline \multirow[t]{2}{*}{31} & 79.48 & 69.2 & 0.707550 & 9 & 0.707546 & 80 & 83.85 & -27.8 & 0.707461 & 8 & 0.707461 \\
\hline & & & 0.707541 & 9 & & L-Bel-1 & 83.92 & -29.3 & 0.707449 & 8 & 0.707449 \\
\hline \multirow[t]{2}{*}{30} & 79.75 & 63.4 & 0.707522 & 11 & 0.707521 & ${ }^{*}$ Levels & $\mathrm{re}$ in $\mathrm{me}$ & ers from & M1, a promi & nent ma & arl band. \\
\hline & & & 0.707520 & 11 & & Errors & 2 stand & ard error & of mass spe & ctromet & tric \\
\hline L-Bel-3 & 79.75 & 63.4 & 0.707515 & 10 & 0.707515 & measuren & nt. Bel & n sampl & number den & otes a b & elemnite. \\
\hline
\end{tabular}

TABLE 1. (continued) 
Published lithological sections show no sedimentological features that might correlate with, and so explain, these low data (J. Schönfeld, personal communication, 1993]. Samples from marl bands, such as M1 (sample 67), and from burrowed horizons (sample 74) do not show unusual ${ }^{87} \mathrm{Sr} /{ }^{86} \mathrm{Sr}$, so neither sample 51, which is between a marl band and a pyritized burrowed horizon, nor sample 46 , which is over $1 \mathrm{~m}$ from any flint, marl, or other sedimentological feature of note, is likely to be affected by locally enhanced diagenetic alteration of ${ }^{87} \mathrm{Sr} /{ }^{86} \mathrm{Sr}$.

Our sample interval at the excursions, coupled with our age model (section 5.5), show that these excursions, if reflecting excursions in marine ${ }^{87} \mathrm{Sr} /{ }^{86} \mathrm{Sr}$, had a duration of $\leq 100 \mathrm{kyr}$. Short-term fluctuations of marine ${ }^{87} \mathrm{Sr} /{ }^{86} \mathrm{Sr}$ have been proposed by others [Capo and DePaolo, 1988; Dia et al., 1992; Clemens et al., 1993] but remain highly controversial [Henderson et al., 1993; McArthur, 1993; Richter and Turekian, 1993]. If such short-term changes are real and the mechanism(s) causing them operated in the Cretaceous, the variations may limit the stratigraphic resolution of $\mathrm{Sr}$ isotope stratigraphy, as currently done by matching ${ }^{87} \mathrm{Sr} /{ }^{86} \mathrm{Sr}$ in different sections, to a level no better than that now attainable as modern methods have analytical errors of about 10 to $20 \times 10^{-6}$. In sections where sedimentation rates were very high, however, repetitive excursions may permit accurate correlation by matching inflections in a manner similar to that done with $\delta^{18} \mathrm{O}$ records.

\subsection{Intercontinental Boundary Correlations}

In Figures 3 and 4, we compare ${ }^{87} \mathrm{Sr} /{ }^{86} \mathrm{Sr}$ across the Santonian/Campanian and Campanian/Maastrichtian boundaries in Lägerdorf/Kronsmoor, the U.S. westem interior, and the English Chalk of Norfolk, United Kingdom. Data are plotted with error bars of 2 s.e. For the European sections we estimate values of ${ }^{87} \mathrm{Sr} /{ }^{86} \mathrm{Sr}$ for stage boundaries using the linear regression of York [1967] between ${ }^{87} \mathrm{Sr} /{ }^{86} \mathrm{Sr}$ and stratigraphic level for samples near the boundary interval, that is, those plotted in Figures 3 and 4. The mean square of weighted deviates (MSWD) was 1.76 for the regression computed for the Campanian/Santonian boundary section in Norfolk; other MSWD values were less than 1.55. The errors on the boundary values are at 2 s.e. and are derived from the regressions. We use linear regression only where data are sufficiently numerous for meaningful results to be obtained. For the U.S. western interior, data are few, so we envelope this data and take the midpoint of the envelope as the boundary value and the limits of the envelope as its error. Lagerdorf/Kronsmoor. Following recommendations of Birkelund et al. [1984], the base of the Campanian in Germany is taken to be at the level of first occurrence of the

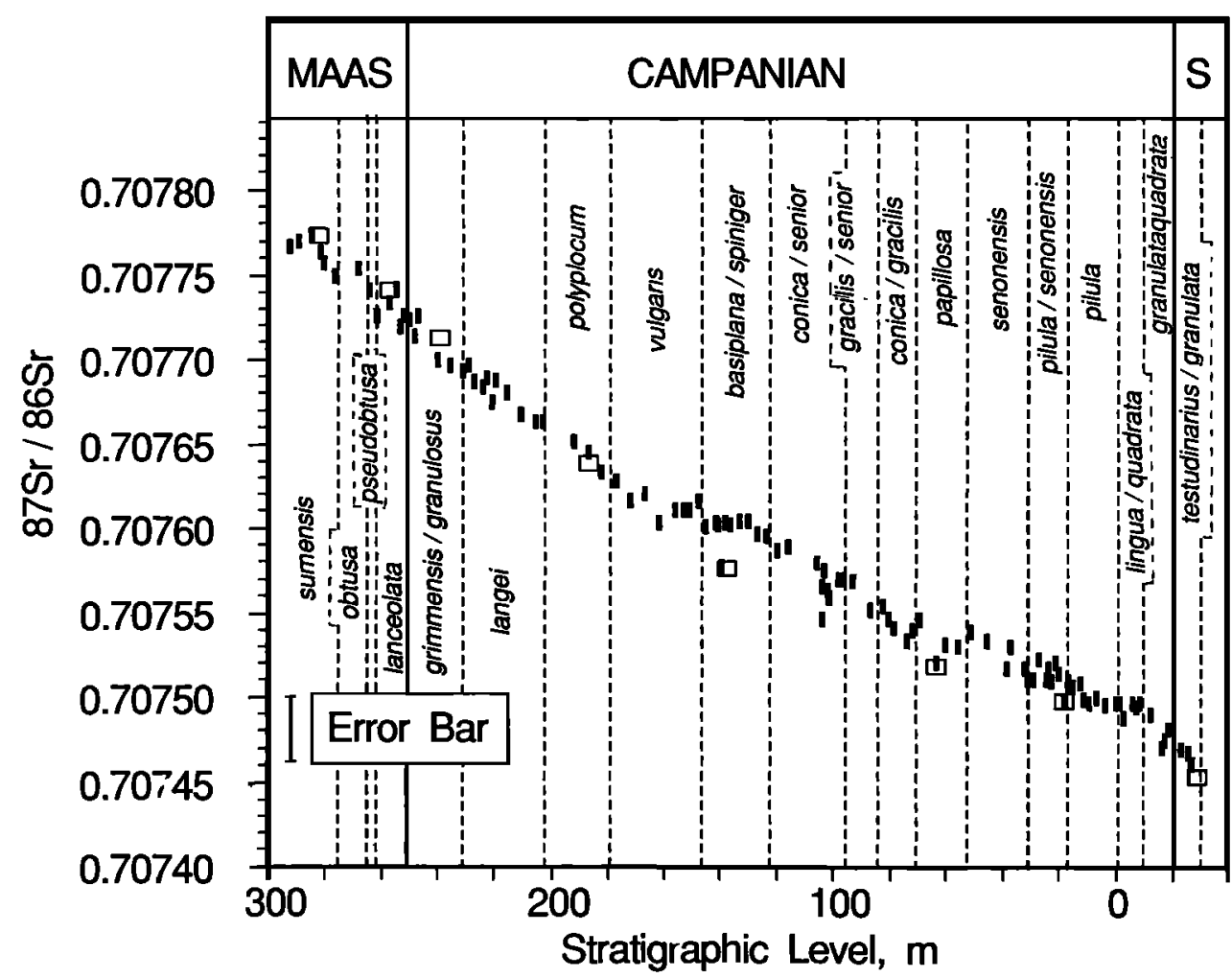

Fig. 2. Strontium isotope ratios as a function of stratigraphic level in the Lägerdorf/Kronsmoor sections. Measurements are in meters from the prominent marl band M1. Macrofossil zones in italics. Open squares represent data for belemnites and vertical bars represent data for bulk nannofossil matrix. The error bar is $\pm 18 \times 10^{-6}$. 

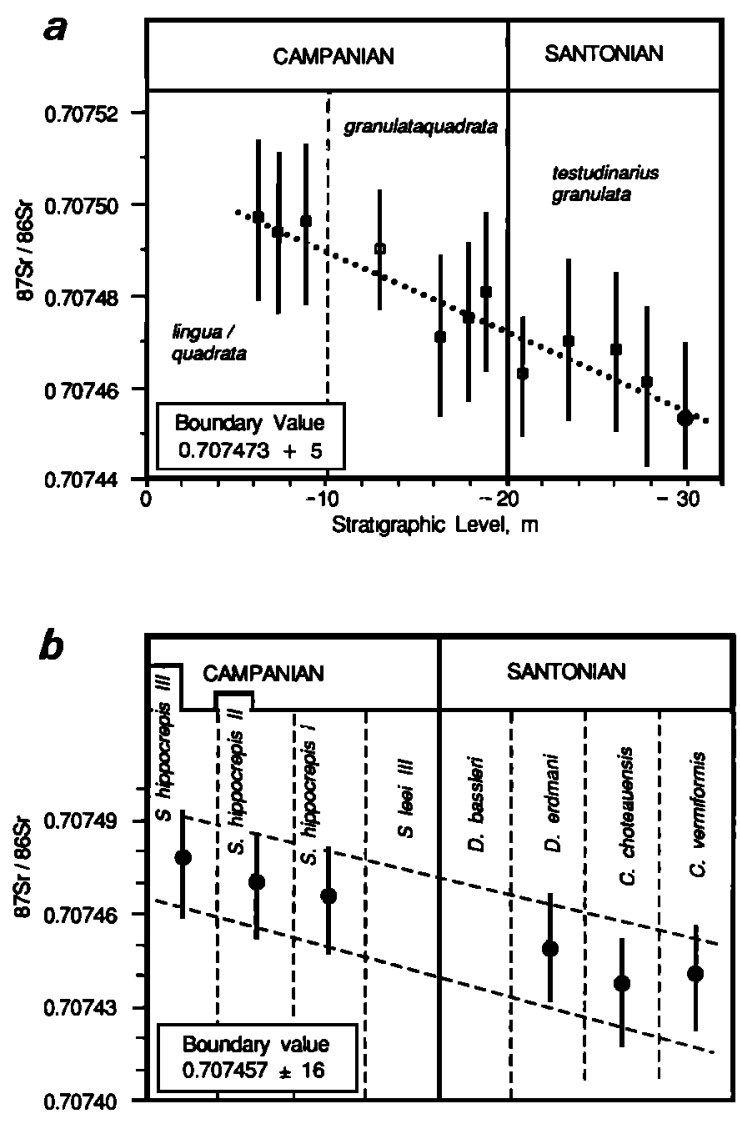

Marcofossil Zone

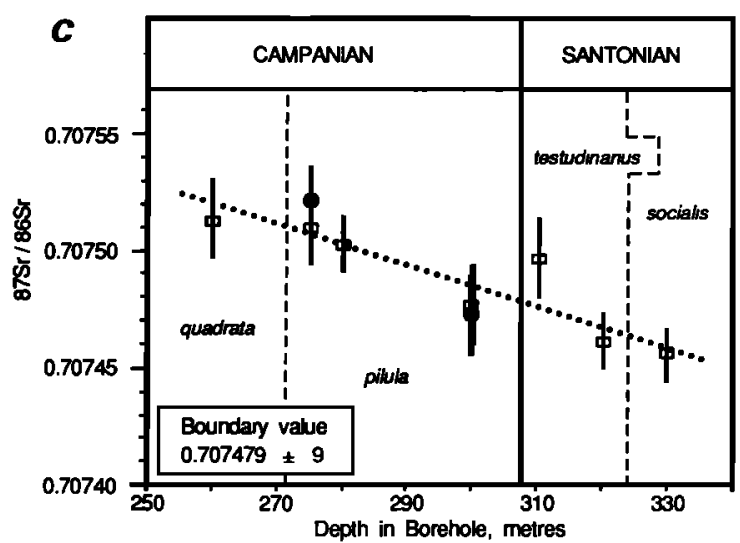

Fig. 3. Trends in strontium isotope ratio across the Santonian/Campanian boundary for (a) Lägerdorf, Germany (b) U.S. western interior, (c) Norfolk, United Kingdom. Errors and error bars are \pm 2 standard errors, except for $3 b$, for which the error on the boundary value is taken as half the envelope width. Open boxes represent nannofossil matrix and filled circles represent macrofossils.
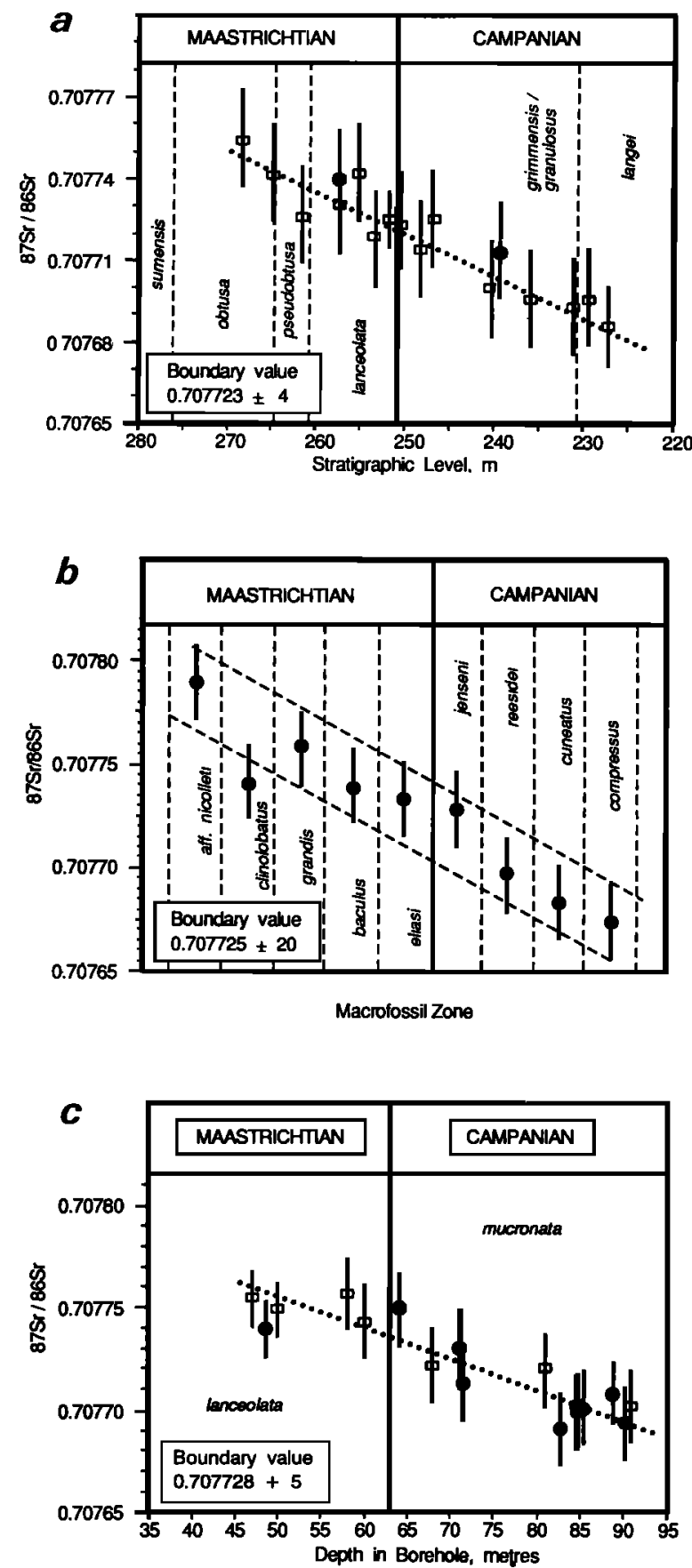

Fig. 4. Trends in strontium isotope ratio across the Campanian/Maastrichtian boundary for (a) Kronsmoor, Germany (b) U.S. western interior, c) Norfolk, United Kingdom. Errors and errors bars are \pm 2 standard errors, except for $3 b$, for which error on boundary value is taken as half the envelope width. Open squares represent nannofossil matrix and filled circles represent macrofossils. 
belemnite Gonioteuthis granulataquadrata and the base of the Maastrichtian is taken to be at the level of first occurrence of the belemnite Belemnella lanceolata. Values of ${ }^{87} \mathrm{Sr} /{ }^{86} \mathrm{Sr}$ at these boundaries are based on York [1967] regression for those data shown in Figures 3 and 4, and are $0.707473 \pm 5$ ( 2 s.e.) for the base of the Campanian at $-20 \mathrm{~m}$ and $0.707723 \pm 4(2$ s.e. $)$ at the base of the Maastrichtian at $251 \mathrm{~m}$. A value for the base of the Maastrichtian may also be calculated from York regression of all the data defining the linear array above $161 \mathrm{~m}$ rather than that close to the boundary. Regression of these $\mathbf{4 0}$ data yields a value for ${ }^{87} \mathrm{Sr} /{ }^{86} \mathrm{Sr}$ of $0.707723 \pm 3$ (2 s.e.). These values apply only to the boundaries as defined here with belemnites [Birkelund et al., 1984].

The U.S. western interior. The ammonite zonation scheme for the U.S. western interior is based on that of Cobban [1984, 1993] and Kennedy and Cobban [1991] with certain modifications, which are discussed in detail by McArthur et al. [1993b]. Numerical dates for the U.S. western interior are those of Obradovich [1993]. In Lägerdorf/Kronsmoor the base of the Campanian, as taken here, is equivalent to the level of last occurrence of the pelagic crinoid Marsupites testudinarius (Schlotheim). In the westem interior, Marsupites extends to the Desmoscaphites bassleri zone, which is here taken to be the highest Santonian zone. We therefore draw the base of the Campanian stage at the base of the overlying zone of Scaphites leei III. The base of the Maastrichtian in the U.S. western interior has been placed by Kennedy et al. [1992] and Kennedy and Cobban [1993] between the ammonite zones of $B$. eliasi and $B$. jenseni, and this placement is accepted here.

Profiles of ${ }^{87} \mathrm{Sr} /{ }^{86} \mathrm{Sr}$ across these boundaries are given in Figures 3 and 4 , where ${ }^{87} \mathrm{Sr} /{ }^{86} \mathrm{Sr}$ is plotted against macrofossil zones, with each zone arbitrarily being given the same width. Also, samples are plotted in the middle of each zone, because there is no way of determining with accuracy the position of samples within their zones, which are often defined by beds of concretion-enclosed fossils in otherwise barren shales. Boundary values for ${ }^{87} \mathrm{Sr} /{ }^{86} \mathrm{Sr}$ and errors given by envelope widths are $0.707457 \pm 16$ for the base of the Campanian and $0.707725 \pm 20$ for the base of the Maastrichtian.

The English Chalk. Details of the macrofossil stratigraphy of the English Chalk at Trunch, Norfolk, are given by Gallois and Morter [1975] and Wood and Morter [1994] and are reproduced in McArthur et al. [1992, 1993a]. For the Trunch borehole, stratigraphic levels are given in meters below surface level. The base of the Campanian, at $307.4 \mathrm{~m}$, is placed at the last occurrence of the pelagic crinoid Marsupites testudinarius (Schlotheim), and the base of the Maastrichtian, at $62.5 \mathrm{~m}$, is placed at the first occurrence of Belemnella sp. in correlative beds on the Norfolk coast. The uncertainty in the positioning of these boundaries in the borehole is no more than $\pm 3 \mathrm{~m}$ [McArthur et al. 1993a]. Profiles of ${ }^{87} \mathrm{Sr} /{ }^{86} \mathrm{Sr}$ across the Santonian/Campanian and Campanian/Maastrichtian boundaries in the section are shown in Figures 3 and 4. Macrofossil data are scarce, because the borehole core provided only a small volume of sediment to sample, so we constrain the trend with data for nannofossil chalk corrected for diagenesis by subtracting $30 \times 10^{6}$ from ${ }^{87} \mathrm{Sr} /{ }^{86} \mathrm{Sr}$ values [McArthur et al. 1993a, McArthur, 1993]. Boundary values for ${ }^{87} \mathrm{Sr} /{ }^{86} \mathrm{Sr}$ are $0.707479 \pm 9(2$ s.e.) for the base of the
Campanian at $307.4 \mathrm{~m}$ and $0.707728 \pm 5$ (2 s.e.) for the base of the Maastrichtian at $62.5 \mathrm{~m}$.

\subsection{Isotopic Correlation Between U.S. Western Interior and Lagerdorf/Kronsmoor}

The zonation scheme for the U.S. western interior is based on ammonites. These are rare in the European Chalk, which is zoned with a variety of other fossils. Boundaries rarely coincide when defined by different fossil groups, and integration of different schemes can be difficult. Isotopic correlation can assist such integration, and this is done in Figure 5, where zones of the U.S. western interior are correlated with the zones of Lägerdorf/Kronsmoor using the ${ }^{87} \mathrm{Sr} /{ }^{86} \mathrm{Sr}$ of the bases of zones in each area, which are given in Tables 2 and 3. The ${ }^{87} \mathrm{Sr} /{ }^{86} \mathrm{Sr}$ of the bases of western interior zones are summarized from the work of McArthur et al. $[1993 b]$. The ${ }^{87} \mathrm{Sr} /{ }^{86} \mathrm{Sr}$ of the bases of zones in the German section were estimated from Figure 2; negligibly different values are obtained through the use of the linear regression fits. If a constant sedimentation rate is assumed for the German sections (see section 5.5), the relative thicknesses of the U.S. zones in Figure 5 represent the relative durations of the zones.

A marked variation in duration is apparent from Figure 5. From the zone of Clioscaphites vermiformis (Santonian) to the zone of Scaphites hippocrepis II (Lower Campanian in the U.S. sense), durations were short compared to overlying zones. The three zones succeeding the zone of Scaphites hippocrepis II each had a duration about $70 \%$ longer than that of its underlying neighbor, so the duration of the zone of Baculites sp. (weak flank ribs) was 5 times that of the zone of Scaphites hippocrepis II. The duration of these zones, as reflected in lithological thickness in many sections, suggests that the zones of Baculites sp. (smooth) and S. hippocrepis III were about equal in duration and both were 0.3 to 0.5 times the duration of the zone of Baculites sp. (weak flank ribs) (W. A. Cobban, personal communication, 1992). Lithological control is inadequate to estimate a duration for the zone of $S$. hippocrepis II but suggests that the zones of $S$. leei III and $S$. hippocrepis I were about equal in duration, and that the zones of Desmoscaphites bassleri and $D$. erdmanni were very short (W. A. Cobban, personal communication, 1992). Our isotopic correlation (Figure 5) probably overestimates the duration of the zone of $B$. sp. (smooth), but reflects and refines the presumed durations of the other zones. In particular, Figure 5 suggests a short duration for the zone of S. hippocrepis II and approximately equal and short zone durations for all the Santonian and Lower Campanian zones discussed here. The inflection in the Middle Campanian prevents correlation in this interval. The duration of overlying zones from $D$. nebrascence to $B$. grandis vary by a factor of two between the shortest ( $B$. jenseni) and longest (Didymoceras cheyennense/D. nebrascence), zone durations that are in general accord with the relative durations estimated from lithological thickness at Red Bird, Wyoming [Gill and Cobban, 1966]. The exception is the duration of the $D$. stevensoni zone, which is much thinner at Red Bird than our Figure 5 predicts. Given the problems of interpreting time from lithological thickness, however, the agreement seems good. 
TABLE 2. Stratigraphic Levels Above $\mathrm{M} 1$ and Derived $87 \mathrm{Sr} / 86 \mathrm{Sr}$ for the Bases of Macrofossil Zones in Lagerdorf / Kronsmoor

\begin{tabular}{|c|c|c|c|}
\hline Base of Zone & Level, m & $\begin{array}{c}\text { Age, } \\
\text { Ma }\end{array}$ & $87 \mathrm{Sr} / 86 \mathrm{Sr}$ \\
\hline Belemnella sumensis & 276.0 & 70.17 & 0.707758 \\
\hline Belemnella obtusa & 264.5 & 70.69 & 0.707740 \\
\hline Belemnella pseudobtusa & 261.0 & 70.85 & 0.707734 \\
\hline Belemnella lanceolata & 251.0 & 71.30 & 0.707723 \\
\hline $\begin{array}{l}\text { Micraster grimmensis / } \\
\text { Cardiaster granulosus }\end{array}$ & 231.0 & 72.20 & 0.707694 \\
\hline Belemnitella langei & 202.0 & 73.51 & 0.707655 \\
\hline Bostrychoceras polyplocum & 179.0 & 74.54 & 0.070630 \\
\hline Galerites vulgaris & 147.0 & 75.98 & 0.707608 \\
\hline $\begin{array}{l}\text { Galeola papillosa basiplana / } \\
\text { Trachyscaphites spiniger }\end{array}$ & 112.5 & 77.54 & 0.707583 \\
\hline $\begin{array}{l}\text { Ehinocorys conica / } \\
\text { Belemnitella mucronata senior }\end{array}$ & 96.0 & 78.28 & 0.707567 \\
\hline $\begin{array}{l}\text { Gonioteuthis quadrata gracilis / } \\
\text { Belemnitella mucronata senior }\end{array}$ & 83.0 & 78.86 & 0.707551 \\
\hline $\begin{array}{l}\text { Ehinocorys conica / } \\
\text { Gonioteuthis quadrata gracilis }\end{array}$ & 70.0 & 79.45 & 0.707536 \\
\hline Galeola papillosa & 52.5 & 80.24 & 0.707530 \\
\hline Galeola senonensis & 31.0 & 81.20 & 0.707519 \\
\hline $\begin{array}{l}\text { Offaster pilula / } \\
\text { Galeola senonensis }\end{array}$ & 18.5 & 81.77 & 0.707510 \\
\hline Offaster pilula & 0.0 & 82.60 & 0.707498 \\
\hline $\begin{array}{l}\text { Inoceramus lingua / } \\
\text { Gonioteuthis quadrata }\end{array}$ & -10.0 & 83.05 & 0.707493 \\
\hline Gonioteuthis granulataquadrata & -20.0 & 83.50 & 0.707472 \\
\hline $\begin{array}{l}\text { Marsu pites testudinarius / } \\
\text { Gonioteuthis granulata }\end{array}$ & -31.0 & 84.00 & 0.707456 \\
\hline
\end{tabular}

Inflections in ${ }^{87} \mathrm{Sr} /{ }^{86} \mathrm{Sr}$ of the type seen at $162 \mathrm{~m}$ form event markers for precise correlation; pervasive diagenesis may alter absolute values of ${ }^{87} \mathrm{Sr} /{ }^{86} \mathrm{Sr}$, but relative differences are likely to be retained. The minimum point of the inflection falls in the middle of the $G$. vulgaris zone in Lägerdorf, within $5 \mathrm{~m}$ of sample 58 which is at $162.0 \mathrm{~m}$ and has an ${ }^{87} \mathrm{Sr} /{ }^{86} \mathrm{Sr}$ of 0.707603 (Table 2), and between or in the Baculites gregoryensis and Baculites scotti zones of the western interior, where ${ }^{87} \mathrm{Sr} /{ }^{86} \mathrm{Sr}$ is 0.707582 and 0.707580 , respectively, for zone bases (Table 3). These zones therefore correlate, within the resolution afforded by the isotopic correlations. The ${ }^{87} \mathrm{Sr} /{ }^{86} \mathrm{Sr}$ values for the two inflection minima differ by $23 \times 10^{-6}$ in ${ }^{87} \mathrm{Sr} /{ }^{86} \mathrm{Sr}$ and are therefore within analytical error of each other. These zones cannot at present be correlated precisely on biostratigraphic criteria, but in Germany, the immediately succeeding Bostrychoseras polyplocum zone, and in the U.S western interior the Baculites scotti zone which succeeds the $B$. gregoryensis zone, may be coeval as both are marked by the co-occurrence of Trachyscaphites pulcherrimus Roemer and an undescribed species of Nostoceras.

\subsection{Age Models for Lägerdorf/Kronsmoor}

Numeric ages for the Upper Cretaceous derive almost exclusively from the U.S. western interior, where more than 25 bentonite beds intercalated within the sequence have been dated with the ${ }^{39} \mathrm{Ar} /{ }^{40} \mathrm{Ar}$ method [Obradovich, 1993]. We use relevant dates to derive our age model. Numeric-age calibration of the German sections can be accomplished with two age models, namely (1) by using the isotopic correlation between the U.S. western interior and Germany (Figure 5) to place western interior dates within the German section or (2) by correlating numeric ages biostratigraphically between the two areas at levels where precise correlation can be achieved, and then interpolating ages within the German section on the assumption that sedimentation rate is constant between the dated levels. The two levels best constrained numerically and biostratigraphically are the base of the Maastrichtian $(71.3 \pm 0.5 \mathrm{Ma})$ and the base of the Campanian $(83.5 \pm 0.5 \mathrm{Ma})$. These levels are precisely correlated between the United States and Europe [Kennedy et al., 1992; Kennedy and Cobban, 1993; Hancock et al., 1992; Hancock, 
TABLE 3. Numeric Ages and Derived 87Sr/86Sr for the Bases of Macrofossil Zones in the U.S. Western Interior

\begin{tabular}{|c|c|c|}
\hline Base of Zone & Age, Ma & $87 \mathrm{Sr} / 86 \mathrm{Sr}$ \\
\hline Hoploscaphites nicolleti & 69.0 & 0.707780 \\
\hline Hoplosca phite aff. nicolleti & 69.2 & 0.707760 \\
\hline Baculites clinolobatus * & 69.9 & 0.707750 \\
\hline Baculites grandis & 70.4 & 0.707750 \\
\hline Baculites baculus & 70.9 & 0.707740 \\
\hline Baculites eliasi & 71.3 & 0.707725 \\
\hline \multicolumn{3}{|c|}{ Campanian / Maastrichtian Boundary at $71.3 \mathrm{Ma}$} \\
\hline Baculites jenseni & 71.9 & 0.707720 \\
\hline Baculites reesidei & 74.0 & 0.707700 \\
\hline Baculites cuneatus & 72.9 & 0.707688 \\
\hline Baculites compressus * & 73.4 & 0.707670 \\
\hline Didymoceras cheyennense & 74.3 & 0.707650 \\
\hline Exiteloceras jenneyi * & 75.0 & 0.707635 \\
\hline Didymoceras stevensoni & 75.6 & 0.707620 \\
\hline Didymoceras nebrascence * & 76.1 & 0.707600 \\
\hline Baculites scotti & 76.6 & 0.707580 \\
\hline Baculites gregoryensis & 77.1 & 0.707582 \\
\hline Baculites perplexus & 78.7 & 0.707590 \\
\hline Baculites sp. (smooth) & 79.1 & \\
\hline Baculites asperiformis & 79.5 & \\
\hline Baculites maclearni & 80.0 & \\
\hline Baculites obtusus * & 80.5 & 0.707568 \\
\hline Baculites sp. (weak flank ribs) & 80.9 & 0.707525 \\
\hline Baculites sp. (smooth) & 81.3 & 0.707495 \\
\hline Scaphites hippocre pis III & 81.5 & 0.707475 \\
\hline Scaphites hippocrepis II & 82.1 & 0.707469 \\
\hline Scaphites hippocrepis I & 82.9 & 0.707462 \\
\hline Scaphites leei III & 83.5 & 0.707457 \\
\hline \multicolumn{3}{|c|}{ Santonian / Campanian Boundary at $83.5 \mathrm{Ma}$} \\
\hline Desmoscaphites bassleri * & 84.1 & 0.707450 \\
\hline Desmosca phites erdmanni & 84.7 & 0.707442 \\
\hline Clioscaphites choteauensis & 85.3 & 0.707438 \\
\hline Cliosca phites vermiformis & 85.9 & 0.707430 \\
\hline
\end{tabular}

* Zones containing dated bentonites.

Italicized ratios are interpolated from adjacent zones.

The error on isotope ratios is less than +0.000018 (see sections 4 and 5.4 of text).

1993], and their numerical ages have been determined precisely by Obradovich [1993] using ${ }^{39} \mathrm{Ar} /{ }^{40} \mathrm{Ar}$ analysis of sanidine; these ages agree very well with the $\mathrm{K} / \mathrm{Ar}$ ages for these boundaries given by Obradovich and Cobban [1975] and Obradovich [1988].

The two models give slightly different ages for the German section (Figures 5 and 6 ). In placing numerical ages into our German section we make the subjective choice of the model based on stage boundary correlation, because we have no evidence that sedimentation rate varied much in the German section during the Campanian. We postulate that the major inflections in the German section, which occur in the vulgaris zone at $162 \mathrm{~m}$ and in the lingualquadrata zone at $-6 \mathrm{~m}$ represent levels at which an alteration occurred in the rate of temporal evolution of marine ${ }^{87} \mathrm{Sr} /{ }^{86} \mathrm{Sr}$. We do so because (1) between $150 \mathrm{~m}$ and $162 \mathrm{~m}$ the ${ }^{87} \mathrm{Sr} /{ }^{86} \mathrm{Sr}$ remains constant or decreases upward though at least $10 \mathrm{~m}$ of section, which shows no sedimentological peculiarities that could account for this trend (on a centimeter or decimeter scale a constant sedimentation rate was probably not present in these hemipelagic sediments, as evidenced by the presence of minor variations in lithology, but we believe this influence to be minor) (2) the connecting linear segments of our isotope curve have different slopes, but each shows a close approach to linearity. Linearity can occur only when variation in sedimentation rate is closely in phase with variation in the temporal rate of change of ${ }^{87} \mathrm{Sr} /{ }^{86} \mathrm{Sr}$ and the magnitudes of both variations compensate closely. Such coupling seems to us to be unlikely (3) the data trend closely parallels that seen in data from the English Chalk, some $570 \mathrm{~km}$ from Lägerdorf and Kronsmoor and (4) recent detailed compilations of ${ }^{87} \mathrm{Sr} /{ }^{86} \mathrm{Sr}$ through time [Miller et al., 1988, 1991; Hodell, 1991] suggest that times of abrupt change in the rate of secular evolution of ${ }^{87} \mathrm{Sr} /{ }^{86} \mathrm{Sr}$ separate long periods of linear evolution.

Further Campanian sections need to be profiled for ${ }^{87} \mathrm{Sr} /{ }^{86} \mathrm{Sr}$ in order to test our age model. One section through the English Chalk is available for comparison [McArthur et al., 1993a] for which data are summarized in Table 4; we derive ages for this section with an age model that replicates our model for Germany; that is, a constant sedimentation rate for the Campanian is assumed between the well-dated stage boundaries, which are precisely correlated to the western interior.

Using our preferred age model, we derive the variation of ${ }^{87} \mathrm{Sr} /{ }^{86} \mathrm{Sr}$ with numeric age through the Campanian of Germany that is shown in Figure 6, where it is compared to the ${ }^{87} \mathrm{Sr} /{ }^{86} \mathrm{Sr}$ curve for the U.S. western interior, and to that for the Chalk of Norfolk, United Kingdom, for which numeric ages have been assigned using an age model identical to that used for Germany. Data for these sections agree to within the analytical errors of the data. For the English Chalk around $79 \mathrm{Ma}$, data scatter slightly, because diagenesis has affected about $30 \mathrm{~m}$ of section as a result of hardground formation, and this has altered ${ }^{87} \mathrm{Sr} /{ }^{86} \mathrm{Sr}$ slightly [McArthur et al., 1993a, McArthur, 1993].

For the German section, York [1967] regression of ${ }^{87} \mathrm{Sr} /{ }^{86} \mathrm{Sr}$ with either age or stratigraphic height in the section yields relationships useful for predicting age or place in the section from ${ }^{87} \mathrm{Sr} /{ }^{86} \mathrm{Sr}$. The rates of change of ${ }^{87} \mathrm{Sr} /{ }^{86} \mathrm{Sr}$ with age and with stratigraphic level can also be derived from these regressions. Errors at 2 s.e., predicted from the regressions, are computed for ${ }^{87} \mathrm{Sr} /{ }^{86} \mathrm{Sr}$ at the extremes of the regression lines, where errors are at a maximum. For the three arrays, the regressions and derivatives are

\section{5 to $74.6 \mathrm{Ma}$}

Age $(\mathrm{Ma})=24463.00-34465.52 \times\left({ }^{87} \mathrm{Sr} /{ }^{86} \mathrm{Sr}\right)$

Height $(m)=769230.77 \times\left({ }^{77} \mathrm{Sr} /{ }^{86} \mathrm{Sr}\right)-544152.31$

Correlation coefficient $=0.99 ; \quad$ MSWD $=0.44$

$2 \times$ standard error on age estimate $\leq 0.22$ m.y.

$2 \mathrm{x}$ standard error on height estimate $\leq 4.9 \mathrm{~m}$

$\Delta^{87} \mathrm{Sr} /{ }^{86} \mathrm{Sr} / \mathrm{m} . \mathrm{y} .=29 \times 10^{6}$

$\Delta^{87} \mathrm{Sr} /{ }^{85} \mathrm{Sr} /$ meter of section $=1.3 \times 10^{-6}$ 


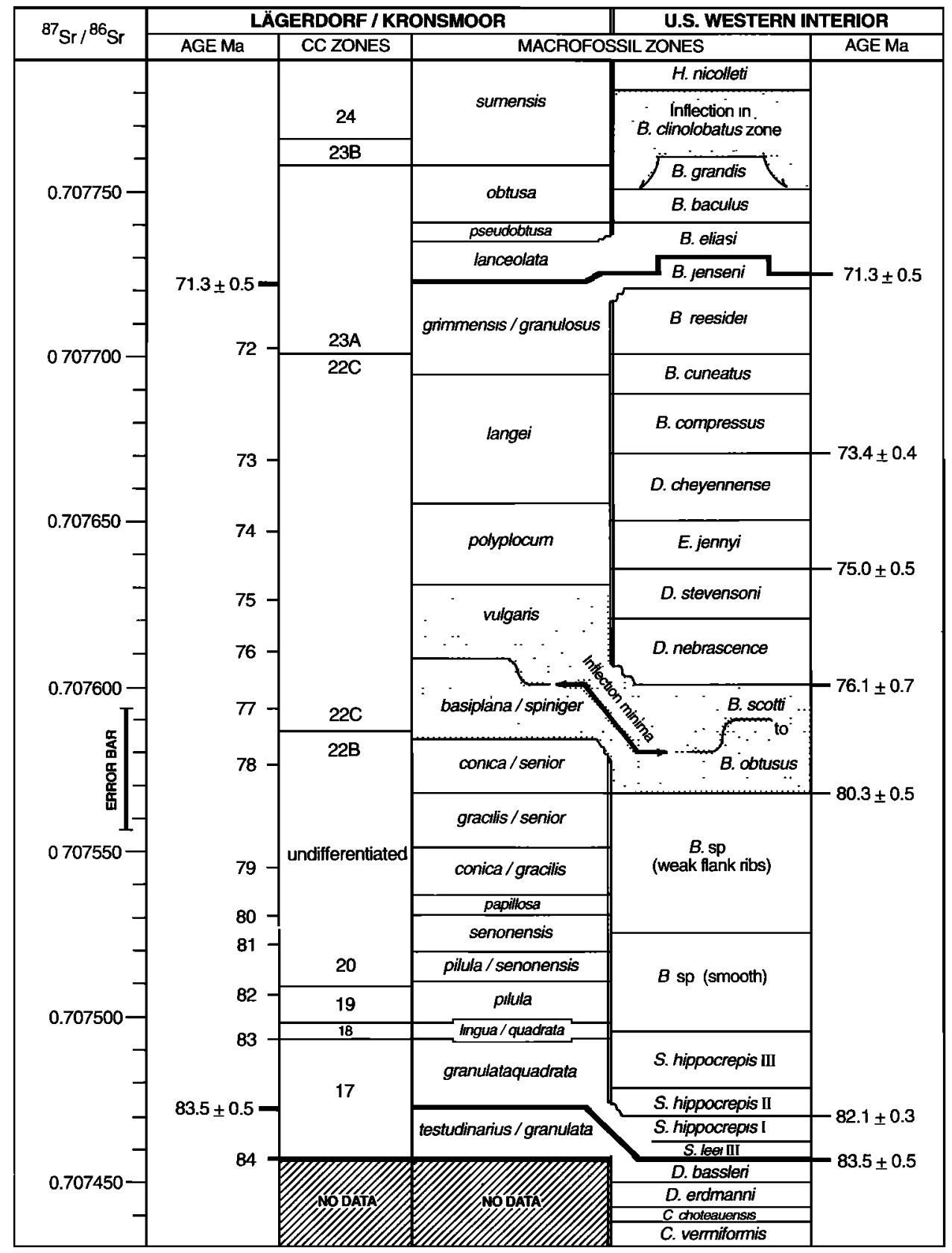

Fig. 5. Strontium isotopic correlation of cephalopod zones in the U.S. western interior to the macrofossil and calcareous nannofossil zones of Lägerdorf/Kronsmoor, Germany. The ${ }^{87} \mathrm{Sr} /{ }^{86} \mathrm{Sr}$ values of the bases of the zones were estimated from Figure 2 for Lägerdorf/Kronsmoor, and from data in McArthur et al. [1993b] (of which Table 3 is a partial summary) for the U.S. western interior. The error bar is $\pm 18 \times 10^{-6}$.

Between 74.7 Ma $(0.707614,167 \mathrm{~m})$ and $76.3 \mathrm{Ma}(0.707599$, $142 \mathrm{~m}$ ) duplicate ages and levels result from overlap of regressions, so there is no resolution in this interval.

76.4 to $82.1 \mathrm{Ma}$

Age $(\mathrm{Ma})=42177.72-59499.02 \times\left({ }^{87} \mathrm{Sr} /{ }^{86} \mathrm{Sr}\right)$
Height $(\mathrm{m})=1333333.33 \times\left({ }^{87} \mathrm{Sr} /{ }^{86} \mathrm{Sr}\right)-943322.67$

Correlation coefficient $=0.96 ;$ MSWD $=1.04$

$2 \mathrm{x}$ standard error on age estimate $\leq 0.30 \mathrm{~m} . \mathrm{y}$.

$2 \mathrm{x}$ standard error on height estimate $\leq 6.7 \mathrm{~m}$

$\Delta^{87} \mathrm{Sr} /{ }^{86} \mathrm{Sr} / \mathrm{m} . \mathrm{y} .=17 \times 10^{6}$

$\Delta^{87} \mathrm{Sr} /{ }^{86} \mathrm{Sr} /$ meter of section $=0.8 \times 10^{-6}$ 


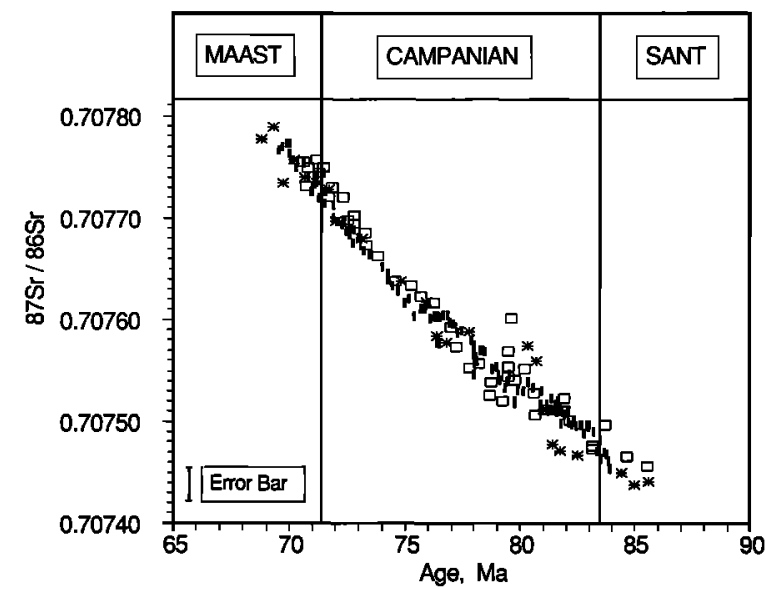

Fig. 6. Strontium isotope ratios as a function of numeric age, where ages for the European sections are derived by interpolation between stage boundaries. Vertical bars are Lägerdorf/Kronsmoor, Germany; asterisks are U.S. western interior; open squares are Norfolk, United Kingdom. The error bar is $\pm 18 \times 10^{6}$.

Between 82.2 Ma $(0.707500,10 \mathrm{~m})$ and $83.4 \mathrm{Ma}(0.707478$, $-17 \mathrm{~m}$ ) duplicate ages and levels result from overlap of regressions, so there is no resolution in this interval.

83.5 to $84.0 \mathrm{Ma}$

Age $(\mathrm{Ma})=18076.20-25432.35 \times\left({ }^{87} \mathrm{Sr} /{ }^{86} \mathrm{Sr}\right)$

Height $(m)=568181.82 \times\left({ }^{87} \mathrm{Sr} /{ }^{86} \mathrm{Sr}\right)-401993.18$

Correlation coefficient $=0.88 ; \mathrm{MSWD}=0.34$

$2 \mathrm{x}$ standard error on age estimate $\leq 0.19 \mathrm{~m} . \mathrm{y}$.

$2 \times$ standard error on height estimate $\leq 4.6 \mathrm{~m}$

$\Delta^{87} \mathrm{Sr} /{ }^{86} \mathrm{Sr} / \mathrm{m} . \mathrm{y} .=39 \times 10^{6}$

$\Delta^{87} \mathrm{Sr} /{ }^{86} \mathrm{Sr} /$ meter of section $=1.8 \times 10^{-6}$

\subsection{Correlation to Lägerdorf/Kronsmoor}

Correlation to Germany can be achieved by comparing ${ }^{87} \mathrm{Sr} /{ }^{86} \mathrm{Sr}$ in unknowns with the Lägerdorf/Kronsmoor data by (1) the use of the York [1967] regressions given above or (2) by direct comparison to the data trend in Figure 2, if linearity is not assumed. For the former case, the 2 s.e. errors of estimate of height and numerical age are derived from the regression and are given above. For the latter case, a useful approximation to total error ( 2 s.e.) may be computed using the formula

2 s.e.tolal $=2\left(\text { s.e. }{ }_{1}^{2}+\text { s.e. }_{2}^{2}\right)^{1 / 2}$

where s.e. 1 is the standard error of the curve and s.e.2 is the standard error of the sample measurement. The standard error of the curve, if linearity is not assumed, will be $\pm 5 \times 10^{6}$, because each data point is constrained by two neighbours so 2 s.e. $=2$ s.d. $/(3)^{1 / 2}$, where the standard deviation for single measurements of ${ }^{87} \mathrm{Sr}{ }^{86} \mathrm{Sr}$ is $\pm 9 \times 10^{-6}$. With our data there is therefore a total error in correlation of $\pm 21 \times 10^{-6}(2$ s.e. $)$ if nonlinearity is assumed. With this error, resolution in dating and correlation is no better than $\pm 0.7 \mathrm{~m}$.y. and $\pm 16 \mathrm{~m}$ of section for strata above $167 \mathrm{~m}, \pm 1.3 \mathrm{~m} . \mathrm{y}$. and $\pm 28 \mathrm{~m}$ of section for strata between $142 \mathrm{~m}$ and $10 \mathrm{~m}$, and $\pm 0.5 \mathrm{~m} . \mathrm{y}$. and $\pm 12 \mathrm{~m}$ of section for strata between $-17 \mathrm{~m}$ and $-30 \mathrm{~m}$. If

TABLE 4. Stratigraphic Levels, Numeric Ages, and 87Sr/86Sr for Nannofossil and Macrofossil Samples from the Campanian / Maastrichtian and Santonian / Campanian Boundaries in the Trunch Borehole, Norfolk, United Kingdom

\begin{tabular}{|c|c|c|c|c|}
\hline $\begin{array}{c}\text { Sample } \\
\text { Number }\end{array}$ & $\begin{array}{c}\text { Depth, } \\
\text { m }\end{array}$ & $\begin{array}{l}\text { Age, } \\
\mathrm{Ma}\end{array}$ & $87 \mathrm{Sr} / 86 \mathrm{Sr}$ & Error \\
\hline \multirow[t]{2}{*}{1} & 47.0 & 70.53 & 0.707785 & 8 \\
\hline & & & 0.707785 & 9 \\
\hline \multirow[t]{2}{*}{ belemnite } & 48.6 & 70.63 & 0.707731 & 7 \\
\hline & & & 0.707748 & 8 \\
\hline \multirow[t]{2}{*}{3} & 50.0 & 70.68 & 0.707773 & 9 \\
\hline & & & 0.707785 & 7 \\
\hline 4 & 58.0 & 71.08 & 0.707787 & 7 \\
\hline 5 & 60.0 & 71.18 & 0.707773 & 9 \\
\hline \multicolumn{5}{|c|}{ Maastrichtian - Campanian Boundary at $62.5 \mathrm{~m}$} \\
\hline Cretirhynchia sp. & 64.2 & 71.38 & 0.707749 & 8 \\
\hline 8 & 68.0 & 71.57 & 0.707751 & 8 \\
\hline 9 & 71.0 & 71.72 & 0.707760 & 8 \\
\hline brachiopod & 71.1 & 71.73 & 0.707728 & 8 \\
\hline brachiopod & 71.5 & 71.75 & 0.707713 & 6 \\
\hline 10 & 81.0 & 72.22 & 0.707750 & 8 \\
\hline inoceramid & 82.9 & 72.32 & 0.707690 & 10 \\
\hline belemnite & 84.8 & 72.41 & 0.707698 & 8 \\
\hline \multirow[t]{2}{*}{ belemnite } & 84.9 & 72.42 & 0.707720 & 9 \\
\hline & 84.9 & & 0.707681 & 9 \\
\hline belemnite & 85.2 & 72.43 & 0.707701 & 9 \\
\hline \multirow[t]{2}{*}{ inoceramid } & 88.8 & 72.61 & 0.707694 & 10 \\
\hline & 88.8 & & 0.707721 & 8 \\
\hline inoceramid & 90.2 & 72.68 & 0.707694 & 9 \\
\hline 11 & 91.0 & 72.72 & 0.707732 & 12 \\
\hline 28 & 260 & 81.14 & 0.707542 & 7 \\
\hline 5777 & 275 & 81.89 & 0.707540 & 11 \\
\hline oyster & 275 & 81.89 & 0.707522 & 9 \\
\hline \multirow[t]{2}{*}{30} & 280 & 82.14 & 0.707544 & 9 \\
\hline & & & 0.707519 & 8 \\
\hline 32 & 300 & 83.13 & 0.707506 & 13 \\
\hline inoceramid & 300 & 83.13 & 0.707472 & 9 \\
\hline \multicolumn{5}{|c|}{ Santonian - Campanian Boundary at $307.4 \mathrm{~m}$} \\
\hline 33 & 310 & 83.63 & 0.707527 & 8 \\
\hline \multirow[t]{2}{*}{34} & 320 & 84.13 & 0.707486 & 10 \\
\hline & & & 0.707504 & 9 \\
\hline \multirow[t]{2}{*}{35} & 330 & 84.63 & 0.707497 & 9 \\
\hline & & & 0.707476 & 9 \\
\hline
\end{tabular}

Errors are 2 standard errors of mass spectrometric measurement. Stratigraphic levels are in meters below ground level. 
accepted as real, the presence of inflections and minor excursions in ${ }^{87} \mathrm{Sr} /{ }^{86} \mathrm{Sr}$ increases these uncertainties. Refinement of the isotope curves is possible with samples more closely spaced, and more replication of ${ }^{87} \mathrm{Sr} /{ }^{86} \mathrm{Sr}$ measurement will reduce the error, so existing methods should enable the determined stratigrapher to achieve, or better, the resolution detailed here.

\section{CONCLUSIONS}

The ${ }^{87} \mathrm{Sr} /{ }^{86} \mathrm{Sr}$ values of samples from the standard section of white Chalk at Lägerdorf and Kronsmoor, northwestern Germany, provide a detailed ${ }^{87} \mathrm{Sr} /{ }^{86} \mathrm{Sr}$ curve for the Campanian. The ${ }^{87} \mathrm{Sr} /{ }^{86} \mathrm{Sr}$ of nannofossil chalk and belemnite calcite from the same stratigraphic level are within analytical error of each other, showing that ${ }^{87} \mathrm{Sr} /{ }^{86} \mathrm{Sr}$ has not been altered by diagenesis. The ${ }^{87} \mathrm{Sr} /{ }^{86} \mathrm{Sr}$ increases upward through $330 \mathrm{~m}$ of section from $\leq 0.70746$ in the Upper Santonian to $\geq 0.70777$ in the Lower Mastrichtian. Three linear data arrays are defined, separated by points of inflection in the Upper Campanian Galerites vulgaris zone and just above the base of the Campanian in the Inoceramus lingua/Gonioteuthis quadrata zone. The linear arrays suggest that the temporal rate of change of marine ${ }^{87} \mathrm{Sr} /{ }^{86} \mathrm{Sr}$ was approximately constant though the periods defined by these arrays. Fine structure in the trends may record brief $\left(<100 \mathrm{kyr}\right.$ ) excursions of ${ }^{87} \mathrm{Sr} /{ }^{86} \mathrm{Sr}$ from values expected from the linear data trends. In Germany, the value of ${ }^{87} \mathrm{Sr} /{ }^{86} \mathrm{Sr}$ at the Santonian/Campanian boundary (level of first occurrence of the belemnite Gonioteuthis granulataquadrata) is $0.707473 \pm 5$. This is within analytical error of values of $0.707457 \pm 16$ at this boundary in the U.S. western interior (base of the Scaphites leei III zone) and $0.707479 \pm 9$ at this boundary in the English Chalk (top of the Marsupites testudinarius zone). In Germany, the value of ${ }^{87} \mathrm{Sr} /{ }^{86} \mathrm{Sr}$ at the Campanian/Maastrichtian boundary (the level of first occurrence of the belemnite Belemnella lanceolata) is $0.707723 \pm 4$. This is within analytical error of the value of the values of $0.707725 \pm 20$ at this boundary in the U.S. western interior (base of the Baculites eliasi zone) and $0.707728 \pm 5$ at this boundary in the English Chalk (defined as in Germany).

Acknowledgments. This work was supported by NERC Research Grant GR3/7716. We thank the following for their significant contributions to this work: J. M. Hancock and J. A. Burnett for collecting samples from Lägerdorf; J. Schōnfeld for guidance in the field, and additional samples from Lägerdorf; W. A. Cobban for samples from the U.S. western interior and valuable discussion and guidance in the field; J. D. Obradovich, for prepublication access to his new Cretaceous timescale; and the British Geological Survey (particularly C. Wheatley), for samples from the Trunch borehole and unpublished stratigraphic information. The Radiogenic Isotope Laboratory at RHBNC is supported, in part, by the University of London as an Intercollegiate Facility. We thank G. Ingram, C. Jenkin, and O. Mc Laughlin for help with the isotopic determinations and
A. Osborn for assistance with sample preparation. J. Baker drew Figures 5 and 6 and M. Gray provided photographic assistance. We thank P. Koepnick, K.G. Miller, J.D. Obradovich, and P. Sugarman for constructive reviews and for suggestions that have improved the paper.

\section{REFERENCES}

Birkelund, T., J.M. Hancock, M.B. Hart, P.F. Rawson, J. Remane, F. Robaszynski, F. Schmid and F. Surlyk. Cretaceous stage boundaries: proposals, Bull. Geol. Soc. Den., 33, 3-20, 1984.

Burnett, J.A., A new nannofossil zonation scheme for the boreal Campanian, Internat. Nannoplankton Assoc. Newsl. 12(3), 67-70, 1990.

Capo, R.J. and D.J. DePaolo, Seawater strontium isotopic variations from 2.5 million years ago to the present, Science, 249, 51-55, 1988.

Clemens, S.C., J.W. Farrell and L.P. Gromet, Synchronous changes in seawater strontium isotope composition and global climate, Nature, 363, 607-610, 1993.

Cobban, W.A., Mid-Cretaceous ammonite zones, western interior, United States, Bull. Geol. Soc. Den., 33, 71-89, 1984.

Cobban, W.A., Migration routes and phyletic development of Upper Cretaceous ammonites, Western Interior, United States, in Evolution of the Western Interior Foreland Basin, edited by W.G.E. Caldwell, Geol. Assoc. Can. Spec. Pap., in press, 1993.

Dia, A.N., A.S. Cohen, R.K. O'Nions and N.J. Shackleton, Seawater Sr isotope variation over the past $300 \mathrm{kyr}$ and influence of global climate cycles, Nature, 356, 786-788, 1992.

Elderfield, H., Strontium isotope stratigraphy, Palaeogeogr. Palaeoclimatol. Palaeoecol., 57, 71-90, 1986.

Ernst, G., Stratigraphische und gesteinschemische Untersuchungen im Santon und Campan von Lägerdorf (SW Holstein), Mitt. Geol. Staatsinst. Hamburg, 35, 71-127, 1963.

Gallois, R.W. and A.A. Morter, East Anglia and South-East England District: Mundesley (132) sheet, Trunch borehole (TG 2933 3455), Rept. Inst. Geol. Sci. U.K., 76(10), 8-10, 1975.

Gill, J.R. and W.A. Cobban, The Red Bird section of the Upper Cretaceous Pierre Shale in Wyoming, U.S. Geol. Surv. Prof. Pap. 393-A, 1-73, 1966.

Hancock, J.M., Ammonite time scales for the Cretaceous, Cretaceous Res., 12, 259-291, 1991.

Hancock, J.M., Transatlantic correlation in the Campanian-Maastrichtian stages by eustatic changes of sea level, in High Resolution Stratigraphy, edited by E. Hailwood and R. Kidd, Geol. Soc. London Spec. Publ., 70, 241-256, 1993.

Hancock, J.M., E.E. Russell, R.H. Taylor and A.S. Gale, The relative stratigraphic position of the foraminiferal and belemnite standards for the Campanian-Maastrichtian boundary. Geol. Mag., 129(6), 787-792, 1992. 
Henderson, G.M., R.K. O'Nions and N.J. Shackleton, Srisotopes in Quaternary planktonic foraminifera from the Pacific and Indian oceans. Eos Trans. AGU, 74(16), Spring Meeting suppl., 176, 1993.

Hodell, D.A., Variations in the strontium isotopic composition of seawater during the Neogene. Geology, 19, 24-27, 1991.

Kennedy, W.J. and W.A. Cobban, Coniacian ammonite faunas from the United States western interior. Special Papers in Palaeontology, 45, 1-96, The Palaeontological Association, London, 1991.

Kennedy, W.J. and W.A. Cobban, Ammonites from the Saratoga Chalk (Upper Cretaceous), Arkansas, U.S.A., J. Paleontol., 67, 406-434, 1993.

Kennedy, W.J., W.A. Cobban and G.R. Scott, Ammonite correlation of the uppermost Campanian of Western Europe, the U.S. Gulf Coast, Atlantic Seaboard and Western Interior, and the numerical date of the base of the Maastrichtian, Geol. Mag., 129, 497-500, 1992.

Koch, K., Biostratigraphie in der Oberkreide und Taxonomie von Foraminiferen. Geol. Jahrb., A38, 11-123, 1977.

McArthur, J.M. Strontium-isotope stratigraphy in 1993, Terra Nova, in press 1993.

McArthur, J.M., A.R Sahami, M.F. Thirlwall, A.O. Osborn and P.J. Hamilton, Dating phosphogenesis with $\mathrm{Sr}$ isotopes, Geochim. Cosmochim. Acta, 54, 1343-1351, 1990.

McArthur, J.M., W.J. Kennedy, A.S. Gale, M.F. Thirlwall, M. Chen, J.A. Burnett, and J.M. Hancock, Strontium-isotope stratigraphy in the Late Cretaceous: intercontinental correlation of the Campanian/Maastrichtian boundary, Terra Nova, 4, 332-345, 1992.

McArthur, J.M., M.F. Thirlwall, J.A. Burnett, W.J. Kennedy, A.S. Gale, A.R. Lord and D. Mattey, Strontium-isotope stratigraphy in the Late Cretaceous: a refinement, based on the English Chalk. in High Resolution Stratigraphy, edited by E. Hailwood and R. Kidd, Geol. Soc. London Spec. Publ., 70, 195-209, 1993a.

McArthur, J.M., W.J. Kennedy, M. Chen, M.F. Thirlwall and A.S. Gale, Strontium isotope stratigraphy for the Late Cretaceous: direct numeric calibration of the isotope curve for the U.S. Western Interior Seaway, Palaeogeogr. Palaeoclimatol. Palaeoecol., in press, 1993b.

Miller, K.G., M.D. Feigenson, D.V. Kent and R.K. Olson, Upper Eocene to Oligocene isotope $\left({ }^{87} \mathrm{Sr} /{ }^{86} \mathrm{Sr}, \delta 180, \delta 13 \mathrm{C}\right)$ standard section, Deep Sea Drilling Project site 522, Paleoceanography, 3, 223-233, 1988.

Miller, K.G., Feigenson, M.D., Wright, J.D. and Clement, B.M., Miocene isotope reference section, Deep Sea Drilling Project site 608: An evaluation of isotope and biostratigraphic resolution. Paleoceanography, 6, 33-52, 1991.

Obradovich, J.D., A different perspective on glauconite as a chronometer for geologic time scale studies, Paleoceanography, 3, 757-770, 1988.

Obradovich, J.D., A Cretaceous time scale, in Evolution of the Western Interior Foreland Basin, edited by W.G.E. Caldwell, Geol. Assoc. Can. Spec. Pap., in press, 1993.
Obradovich, J.D. and W.A. Cobban, A time-scale for the Late Cretaceous of the Western Interior of North America. in The Cretaceous system in the Western Interior of North America, edited by W.G.E. Caldwell, Geol. Assoc. Can. Spec. Pap., 13, 31-54, 1975.

Perch-Nielsen, K., Calcareous nannofossils from the Cretaceous between the North Sea and the Mediterranean, Int. Union Geol. Sci. Ser., A6, 223-272, 1979.

Perch-Nielsen, K., Mesozoic calcareous nannofossils, in Plankton Stratigraphy, edited by H.M. Bolli, J.B. Saunders and K. Perch-Nielsen, 329-426, Cambridge University Press, Cambridge, United Kingdom, 1985.

Richter, F.M. and K.K. Turekian, Simple models for the geochemical response of the oceans to climatic and tectonic forcing, Earth Planet. Sci. Letters, 119, 121-131, 1993.

Schönfeld, J., Zur Stratigraphie und Ökologie benthischer Foraminiferen im Schreibkreide-richtsprofil von Lägerdorf, Holstein. Dissertation zur Erlangung des Doktorgrades der Mathmatisch-Naturwissenschaftlichen fakultät der Christian Albrechts Universität, Kiel, Germany, 1988.

Schönfeld, J. and J.A. Bumett, Biostratigraphic correlation of the Campanian-Maastrichtian boundary:

Lägerdorf-Hemmoor (northwestern Germany), DSDP Sites 548A, 549 and 551 (eastern North Atlantic) with palaeobiogeographical and palaeoceanographical implications. Geol. Mag., 128, 479-503, 1991.

Schönfeld, J., F. Sirocko and N.O. Jorgensen, Oxygen isotope composition of Upper Cretaceous chalk at Lägerdorf (NW Germany): its original environmental signal and palaeotemperature interpretation, Cretaceous Res., 12, 27-46, 1991.

Schōnfeld, J., M-G Schulz, J.M. McArthur, J.A. Burnett, A.S. Gale, U. Hambach, H.J. Hansen, W.J. Kennedy, K.L. Rassmussen, M.F. Thirlwall and D. Wray, New results on biostratigraphy, palaeomagnetics, geochemistry and correlation from the standard section for the Upper Cretaceous white Chalk of northern Germany (LagerdorfKronsmoor-Hemmoor), in Proceedings of the Fourth International Cretaceous Symposium, Hamburg, in press, 1993.

Schulz, M-G., Zur Litho und Biostratigraphie des Obercampan-Untermaastricht von Lāgerdorf und Kronsmoor (S-W Holstein), Newsletter in Stratigraphy, 7, 73-89, 1978.

Schultz, M-G., Morphometrisch-variationsstatistische Untersuchungen zur Phylogenie der Belemniten-gattung Belemnella im Untermaastricht NW-Europas, Geol. Jahrb., A47, 3-157, 1979.

Schultz, M-G., G. Ernst, H. Ernst and F. Schmid, Coniacian to Maastrichtian stage boundaries in the standard section for the Upper Cretaceous White Chalk of NW Germany (Lāgerdorf-Kronsmoor-Hemmoor): Definitions and proposals, Bull. Geol. Soc. Den., 33, 203-215, 1984.

Sissingh, W., Biostratigraphy of Cretaceous Nannoplankton, Geol. Mijnbouw., 56, 37-65, 1977.

Surlyk, F., Brachiopods from the Campanian-Maastrichtian boundary sequence, Kronsmoor (NW Germany), Geol. Jahrb., A61, 259-277, 1982.

Thirlwall, M.F., Long term reproducibility of multi-collector 
Sr and Nd isotope ratio analysis, Chem. Geol., 94, 85-104, 1991.

Veizer, J., Strontium isotopes in seawater through time, Ann. Rev. Earth Planet. Sci., 17, 141-167, 1989.

Wood, C.J. and A.A. Morter, Biostratigraphy of the Trunch borehole, in Geology of the Country around Great Yarmouth, R.S. Arthurton, S.J. Booth, A.N. Morigi and M.A.W. Abbott, Memoir Br. Geol. Surv., Sheet 162 (England and Wales), in press, 1994.

York, D., The best isochron. Earth Planet. Sci. Letters, 2, 479-482, 1967.

M. Chen and J. M. McArthur, Research School of Geological and Geophysical Science, Birkbeck College and University College London, Gower Street, London WC1E 6BT, England.
A.S. Gale, Palaeontology Department, The Natural History Museum, Exhibition Road, South Kensington, London SW7 5BD. England.

W.J. Kennedy, Department of Earth Sciences, Parks Road, Oxford OX1 3PR, England.

M.F. Thirlwall, Department of Geology, Royal Holloway and Bedford New College, Egham Hill, Egham, Surrey, TW20 0EX, England.

(Received August 13, 1992; revised July 15, 1993; accepted August 16, 1993.) 